\title{
A Variety of Cultures Represented in English Language Textbooks: A Critical Study at Saudi University
}

\author{
Omar Alsaifa
}

\begin{abstract}
Textbooks material is one of the important issues that are worthy to investigate in order to enrich student's engagement and interaction in EFL (English as a Foreign Language) classrooms. In this study, the author argues that textbooks materials used in academic institutions may well take a significant part in generating an active environment in EFL classrooms. It is believed that more opportunities will be created for students to be more involved, active, and able to understand the content being addressed more effectively. Yet, by looking at the textbooks being utilised (at a university context where the author teaches), one can notice that student's culture (Eastern) is to a large extent missing in these textbooks, most of these books instead represent dominantly "Western" culture namely American and British cultures. This can clearly be depicted by topics discussed, pictures, clothing, names, and many other issues portrayed in these textbooks. This study is an attempt to challenge and problematize such domination of Western cultures portrayed in the content of English textbooks used in academic institutions not merely within Saudi Arabia but also extended to other countries and nations in the world.
\end{abstract}

\section{Keywords}

English textbooks materials, language teaching materials, Eastern culture, Western culture, critical study

As an English language teacher from a background where language classrooms, and perhaps other kinds of classes are teacher-dominated, the author has always been interested to find ways within which student interaction can effectively be promoted in such EFL (English as a Foreign Language) setting. In this paper, the author argues that textbooks material is one of the important issues that are worthy to investigate to enrich student's engagement and interaction in EFL classrooms. Looking at the textbooks used (i.e. at a tertiary level where the author teaches), one can notice that student's "Eastern" culture is to a large extent missing in these materials. Most of these books represent dominantly "Western" culture instead, namely American and British cultures.
This can be depicted by topics, pictures, names, clothing, and many other issues portrayed in these textbooks. Yet, if we consider the purpose of learning English for EFL learners, most of them study English either to meet their individual or institutional needs. Researchers such as Mckay (2002) and Kumaravadivelu (2006) suggested that English for such learners is used as "language of communicational necessity, not of cultural identity". Kumaravadivelu (2006b: 19) went on to elaborate that some (other

\footnotetext{
aUniversity of Exeter, UK

Correspondent Author:

Omar Alsaif, 35 Augustus House, New north road, Exeter, EX44HL, United Kingdom
} 
nations or cultures) "see English as 'Trojan Horse', a hidden threat to one's cultural liberty". So in response to this, and as an initial step, this study is an attempt to challenge and problematize the domination of Western cultures portrayed in the content of English textbooks used in academic institutions not merely within Saudi Arabia but also extended to other countries in the world. According to Shin, Eslami, and Chen (2011: 256), "most researchers agree that most current English-as-a-foreign language (EFL) textbooks focus on features of Western culture".

\section{RATIONALE OF THE STUDY}

The study aims to problematize and challenge the predominance of Western culture in EFL textbooks materials. Such domination is currently seen as taken-for-granted issue amongst the majority of academic institutions in the Kingdom of Saudi Arabia (KSA henceforth). The study also aims to raise awareness of Saudi educators in particular and Arabs in general about the significance of presenting a variety of culture that English language represents within EFL textbooks used. EFL learners need to see other cultures that represent English language (e.g. India, Nigeria, and Philippines). English is not the exclusive language for "inner cycle" countries (USA, UK) anymore. Researchers such as Cortazzi and Jin (1999), Siddiqie (2011) argued the use of English as a "lingua franca" by the people, who do not speak it as first language in international situations, rationalizes the inclusion of international cultures in language teaching textbooks (Siddiqie 2011: 109). Furthermore, students need to see that their own culture is represented in these textbooks and not marginalised. By representing student's own culture in English language textbooks, we enable them to talk and elaborate about their own culture (something most native English teachers like to hear about), we provide room and equal opportunities for all parties inside classrooms to participate and talk about their own culture whether it is Eastern or Western culture. Further opportunities are given and created for language learners to practise English and develop their speaking skill and talk about their own culture through classroom activities (Alptekin 1993; Mckay 2002).

It is hoped that such varieties of cultures within textbooks materials will be benefited for EFL learners and aid in creating what is called "intercultural competence". Students can also share knowledge with the teachers, be more interacted, and empower their role in the area of language learning and education. According to Troudi (2005: 124), varieties represented in English textbooks "will be more fruitful to introduce the students to a range of English varieties thus, exposing them to the rich and complex linguistic and cultural reality that accompany the learning of English”.

\section{LITERATURE REVIEW}

\section{The Importance of Textbooks in ELT Program}

The utilisation of textbooks is central to any educational course at least, in a traditional sense and within the bounds of present technology and practice. But this traditional utilisation of textbooks is also subject to its potential invalidation by the progression of technology. Technological advances such as cloud computing, virtual classrooms, and so forth, have not, as yet, resulted in the redundancy of textbooks. Textbooks provide a focal point for the direction of education, and a systematic organisation of concepts in a single place for both students and teacher. They also provide a breakdown of course content that permits the progression of a course in incremental stages. This then allows for successive developments of a course to be engaged in a systematic manner. In addition, in the utilising of textbooks in a central educational role, there is an important factor to take into consideration. This is in relation to the impressionable nature of any process of socialisation, or education in general. That is, when students absorb 
the information in a textbook, they will come to associate the complex of sense-impressions with the objects of their education. This includes, for instance, the depiction of a culture by way of images. In this case, students develop both a lexical understanding of, say English, together with associated values and cultural normativity.

However, specific difficulties apply when considering the usage of textbooks in the context of ELT (English Language Teaching). This is largely centred upon the above point that the material presented in a book will serve as the establishing of the later schemata with which an individual will relate to a language and the culture from which it originates - in this case, English. For instance, if particular images and examples are referred in a textbook, the student will, by way of a psychological association and memory, colour their understanding of the lexicon with the associated images and examples. The major problem that arises in the case of English is from its status as a colonial language. Given its present situation as a major international language - if not the major international language - there exists an uncomfortable tension between the reality of its history, and the problem of continued hegemony. Post-colonial theory arises in defence of the preservation of local cultures, while staving off any continued cultural imperialism. There exists, therefore, the need for a delicate balance between the usage of textbooks in ELT programs, and the careful preparation of textbook content.

\section{A Brief Discussion About the Ongoing Debate for and Against Using Textbooks in ELT Programs}

The following account will provide a brief engagement with the issues surrounding the usage of textbooks in ELT programs, specifically focusing on the case study of ELT in KSA. This will serve as a precursor to the following section, which will provide a literature review of specific debates in publication.
While in an immediate sense, the issue of textbook usage may seem like a simple concept, it is rather far more value-laden than initially apparent. This largely centres around the question of what exactly constitutes the phenomenon of "English" today — and whether we can continue to speak of such a unified and absolute concept as "English" in the face of the more realistic prospect of "Englishes". This latter neologism will be employed henceforth to describe the plurality of varieties of the English language in existence, examples include, but are not limited to, Irish English, Jamaican English, African-American English, and Saudi English. The status of English as a colonial language stems from the history of England's imperialism and its tyranny over other nations, a historical legacy that has resulted in the far-reaching influence of what is today an international language (Smith 1998). But the decline of the Empire has also witnessed the decline of the hegemony of British English, however, there continues to be the presence of an implicit hegemony. This is revealed today in the major hegemonies of both British and American English. So, a major question arises: In what manner should English as such be portrayed in textbooks? Should textbooks teach and propagate British and American colloquialisms and cultural idiosyncrasies (with the latter serving as examples of lexical usage), or should content be localised so as to better fit the culture in which the educational course is situated and is directed? In light of this, it is certainly possible to make a strong case against the teaching of an "English as such". This would then argue in favour of the continued usage of textbooks, but in an explicitly localised context. But there exists a problem with this approach. Solely depicting localised content arguably fosters prejudice towards foreign nations, and in light of terrorist events of the past couple of decades, reenforces xenophobic tensions. This is because the local culture is asserted as a normative standard with an absolute character-which is different to this standard then adopts the status of transgressor. 
In addition, an exclusive focus on local culture does not prepare local students for an engagement with a global economy, leaving them institutionalised, in a sense. As Macedo, Gounari, and Dendrinos (2004) examined, there exists a necessity for an acceptance of history and the fact that English is, today, a major language - but this cannot then permit continued hegemony. As will be explored in the next section, it is certainly possible to argue that there needs to exist a delicate balance in ELT textbooks between content localisation - and of course the primary importance of a respect for Islamic values - and the education about the values of foreign cultures.

\section{Some of Relevant Studies Found in Literature}

A recurring theme in the literature in relation to the usage of textbooks in ELT is the perspective of the post-colonial acceptance of English as an international language on the one hand, and the assertion of cultural autonomy on the other. However, amongst the following papers that will be reviewed, there exists the slightest trace of anti-Western sentiment, levelled particularly at the United Kingdom and the United States of America. There exists therefore a need for a delicate balance between an acceptance of history and the prevention of further hegemony at the level of ELT. Mahboob and Elyas (2014) commented on the fact that English in the KSA is not a "neutral language". It is not value-neutral. Because the concept of English serves as a symbolic representation of an entire system of politics, economics, religion, and culture. And as it may be plausibly observed, Western culture is quite different from that of KSA, with the latter being bound up in Islamic conventions. Some of these are in opposition to Western values, examples of which include conceptions of gender equality, sexual morality, and the ingestion of mood-altering substances. This is of course problematic and as the authors observe, the spread of English as a representation of the phenomenon of cultural imperialism as such, is met with resistance and hostility. This is also an internal problem, articulated by the authors as a "tension between forces for reform and traditional practices", where attitudes vary on the subject of ELT. While reflecting on these tensions, the authors also focus on the specific, above-mentioned problem of content localisation to better avoid the issue of cultural hegemony. This then ultimately results in the proposition of the necessity for the accommodation of "Saudi English", as a distinctive example of the language from the greater pool of Englishes.

Attitudes towards English as a foreign language have changed in the twentieth century, acknowledging the status of English as an international language and the need to rise to meet it, so to speak. But in a sense, this has also reenforced cultural hegemony, as the scholarship preparation school in KSA sought to prepare students to travel to the UK and the USA. This then implicitly demoted local culture in the face of foreign hegemony. Nonetheless, currently, English is taught in public schools due to its "perceived economic value" (Mahboob and Elyas 2014). This, according to the authors, was also influenced by pressure from the USA to promote local tolerance to American culture as such. This then served as a means of accepting the diversities of existent cultures, rather than simply regarding them as "over there", distant, and in opposition to that of the KSA.

While the importance of English as a language is, therefore, self-evident, the authors then turn to the problems associated with ELT. Early incarnations of ELT in KSA employed heavily-censored textbooks, deleting any references to topics that are subject to a taboo in Islamic culture. This includes references to "dating, drinking alcohol, and co-education". But this has now in modern times been revised. Western culture is now portrayed as an example of the diversity of existent cultures. This is problematic, however, and it is important to consider the issues raised by cultural relativism, and the associated problems with depicting Western customs that are offensive to Islamic mores in KSA textbooks. Continuing to depict Western 
culture in such a manner is, then, arguably, a further expression of Western imperialism. This is a very real and disconcerting problem, and to respond to this, the authors reflect on the concept of accommodating textbooks materials which are suitable for Saudi society and its culture. Rather than simply providing an exposition of the problem, the authors then point to the solution. An example of such is the utilisation of expressions such as "Assalamu Alaikum" rather than "hello" in conversational examples in textbooks. This then operates on the premise that history has unfolded in the way it has with the resultant linguistic hegemonies - and while this can be accepted and accommodated, steps must be taken to ensure the autonomy of particular cultures. Here, then, Saudi English serves as an expression of "a local sociocultural worldview" (Mahboob and Elyas 2014). This suggested solution aimed to localise the textbooks is only part of the solution. In the author's view, our students need also to know how such conversation operates in English using English expressions not Arabic ones. Accordingly, the author cannot see any difficulties of presenting both cultures in the textbooks. In one occasion for instance, Western culture can be presented, and on the other one, Eastern culture can similarly be represented throughout different topics within the content of EFL textbooks. By this, we assume that the delicate balance required is somehow achieved.

Another study conducted by Mahib ur Rahman and Alhaisoni (2013) also treated the problem of ELT in KSA, firstly observing that, educational reform has resulted in the present, universal value of literacy and education as such. The study examines the central tenets of education in the Kingdom with it being of a sectarian nature; which is amongst its central aims is the preservation of Islamic culture, values, and ideals. This is parallel to and not less important than individual development and the development of KSA as a whole, economically, culturally, and socially. Interestingly, which is amongst the objectives of the Ministry of Higher Education is the development of
ELT for the purpose of enabling the student to "present and explain Islamic concept (sic) and issues, and to participate in spreading Islam" (Mahib ur Rahman and Alhaisoni 2013: 114). This is complemented by both the development of ELT for the dual purposes of benefitting from the cultural offerings of English-speaking nations, together with acquiring respect and tolerance for those cultures. This is an important aspect of promoting harmony with, and not hostility towards, those cultures. But while any such series of objectives may in theory be ideal, the reality falls short of this idealism somewhat: pointing to several issues in relation to ELT, including the recurring problem of textbook usage. Some of these lie in such arbitrary factors as student aptitude and motivation. In addition to the deficiency of teacher's training programmes and assessment methods employed.

Nonetheless, part of the issue is the fact that educators are indecisive and insecure about the selection of textbooks, based on the aforementioned problem of appropriate content. According to the authors:

These textbooks and materials fail to meet the learners' needs and baffled the syllabus designers and other administrative bodies to find out the best textbook from the market. Like many other countries, the syllabus designers and the higher authorities of various schools and universities of Saudi Arabia are also unable to choose an appropriate textbook for their students. Therefore, selection of appropriate ELT textbooks and materials is another point of concern. (Mahib ur Rahman and Alhaisoni 2013: 115)

In response to this, the authors recommend an overhaul of present ELT practices. This study has also raised a number of issues that should be taken into consideration in order to promote and develop English language teaching in Saudi Arabia. Textbooks material was one of these issues as the study highlighted.

Meanwhile, Nikou and Soleimani (2012) also provided a distinctive treatment of the problem, in the specific context of the Iranian and Turkish 
high-school practice of ELT. They argue that the representation of foreign cultures in textbooks is "too weak" to prepare students for an engagement with foreign English-speaking nations. This includes an over-representation of particular topics (such as science), with a woeful lack of representation of additional aspects of Western culture-particularly those that might deeply contrast with both Iranian and Turkish culture. The authors draw upon previous research to make the claim that together with the desire to learn a foreign language is the social desire to somehow be acquainted with, or to adopt the customs of the foreign culture. This is a plausible claim, but the authors also argue that this need not necessarily be so. They argue, subjecting local students to foreign cultures by way of ELT textbooks "is not necessarily accompanied by jeopardizing their own native culture and it does not mean that one has an obligation to behave in accordance with the conventions of the target culture" (Nikou and Soleimani 2012: 647). Rather, the authors claim, this would allow students to develop "a better understanding of new cultures as well as realising their own identity in a better way" (Nikou and Soleimani 2012: 647).

\section{METHODOLOGY AND RESEARCH QUESTIONS}

As manifested in its objectives, this small-scale critical study aims to problematize and challenge an issue currently taken for granted amongst the majority of Saudi Arabia's universities in general and in the KSA in particular. The problem under critique here is the predominance of Western culture represented within English-language textbooks. Troudi (2014) in his article entitled "Becoming a Critical Researcher in Language Education and TESOL" concluded "If we want to be educators and intellectual teachers rather than consumers and perpetuators of hegemonic structures and dominant discourses, then our research ought not to be stripped of its critical agenda".
The study is informed by a critical paradigm that best serves the main objectives of this study. Critical approach is appropriate for an agenda that aims to challenge, change, or highlight issues related to educational practices such as voice, marginalization, and exclusion. Pennycook (2000) argued that one of the main objectives of critical approaches is to problematize the givens of TESOL (Teaching English to Speakers of Other Languages) and challenge their assumptions, he also encouraged this view. Other researchers such as Kincheloe and McLaren (2002) and Rubin (2012) have asserted that "Research should redress past oppression, bring problems to light and help minorities, the powerless and silenced" (Rubin 2012: 20). Therefore, in order to challenge the Western cultural domination evident in the current materials employed, the study attempts to identify and analyze the embedded content portrayed in these textbooks by utilising critical discourse analysis (CDA). According to Dijk (2008: 352), CDA is a type of discourse analytical research that mainly investigates the way social power abuse, dominance, and inequality is enacted, reproduced, and resisted by text and talk in the social and political context.

CDA can be done through the analysis of language texts (written or spoken). Given the aims of this study, which are mainly to problematize and challenge this predominance of Western culture portrayed in textbooks, CDA has been found to be an appropriate methodology as it operates through communication, which is a key function of human relations (Weber 1990). Textbook as a form of written discourse is a communicative medium through which students may receive different information and messages through the topics depicted in the content of these texts. These topics may influence what students see as the most important information in text or talk, and thus take it for granted. Dijk (2008: 357) suggested that "In some situation participants are obliged to be recipients of discourse, e.g. in education and in many job situations, lessons, learning materials, job instructions, and other 
discourse types in such cases may need to be attended to, interpreted, and learned as intended by institutional or organizational authors" (Giroux 1988). A CDA will therefore expound on these "social, political, cognitive, moral and materials consequences" (Fairclough 2003: 15).

Specifically, the author adopted a textual analysis as an approach to analyze the content of these textbooks (Fairclough 2003). It was employed in the study as it allowed the author to look at the content of these textbooks in terms of the language used, the topics represented, and the prevalent culture portrayed. It allowed the author to understand how the textbooks reinforce or diminish the theme of the unequal distribution of power in a society, in addition to investigating which topics within these textbooks are either overlooked or missing from the text. The final intention was to expose the ideology and political analysis that comes from the text; according to Fairclough (2003: 5), "Textual analysis can often give excellent insights about what is 'in' a text, but what is absent from a text is often just as significant from the perspective of sociocultural analysis". Similarly, Weninger and Kiss (2013) stated, "Critical discourse analysis is one of the common methods of analysing cultural content in teaching materials". It is then hoped that our analysis of these materials will answer the research questions:

(1) Do the English-language textbooks currently used in Taibah University's ELC (English Language Centre) classrooms represent the variety of cultures that English language represents?

(2) How do these textbooks represent the social issues of Saudi and Arab society?

\section{SAMPLE OF THE STUDY}

The study sample consists of four levels of Touchstone textbooks. These textbooks, seen as an innovative new series, are designed for adult and young adult learners in the Arab world ${ }^{1}$ and should take them from the beginning through the intermediate levels of proficiency. Particularly, Touchstone books levels 1 and 2, these two levels, designed for beginners and high beginners, teach basic grammar, vocabulary, and conversation strategies for everyday interaction. These textbooks have been used in the preparatory programme (foundation year) in the university for three years now.

\section{DATA ANALYSIS AND PROCEDURE}

As stated by Nikou and Soleimani (2012: 649), "To date, no specific methodology has been agreed upon for analysing the cultural content of foreign language textbooks". However, the textbook analysis model in this study is based on the textual analysis approach, which is an element of CDA (analysis of written or spoken language texts). The textual analysis approach was also implemented and recommended by Murayama (2000), originally stemming from a modified version by Ramirez and Hall (1990). It was designed and adapted for a similar purpose, because it focused on the cultural content and the levels of cultural information given and presented in EFL materials in a particular context (Japan), which were the main issues under investigation and analysis here. Yet, in order to answer the research questions of the study, the data were analyzed considering two important elements: aspects of cultures and the varieties of cultures represented within the addressed textbook materials. In her study, Murayama used the terms "aspects of cultures" and "levels of cultural understanding" to evaluate cultural content in textbooks; in this study, the author has used a modified term "the varieties of cultural presentation" instead of "levels of cultural understanding". The author has also looked at the ideology and the political analysis that is evident in the texts.

The findings of the study were presented visually using a number of figures (1-7) with different topics and themes taken from the content of Touchstone textbooks. The data were then discussed and analyzed 
qualitatively based on what can be seen and depicted from the topics and pictures presented in these materials.

Table 1 shows the overall topics and themes discussed and analyzed in this study. It also illustrates the types of culture portrayed in most of these topics.

\section{FINDINGS AND DISCUSSIONS}

After analysing the current textbooks being used in a particular context in the KSA, it is evident that Western culture, specifically from "inner circle" countries such as the USA, the UK, and Canada, is predominant in these materials. Such domination is shown throughout seven themes analyzed in the following examples. Themes included common topics within the content of textbook materials as shown in Figure 1.

\section{The Dominance of Western Culture Represented on TV Programmes}

Western culture is represented in the contents of this listening exercise. In Unit 5, Lesson A, students are required to listen to different TV shows and then write the number next to the correct type of TV show they hear. Yet, one can easily recognize that most kinds of TV shows depicted here are mainstream American programmes. Examples include soap operas, talk shows, game shows, and sitcoms (situation comedies). American culture can also be observed by character appearance and clothing in these shows.

These TV shows are popular in the USA. The following quotation supports this finding: "Soap operas became a staple of daytime television in the United States in the early 1950s. Along with gameshows, reruns of situation comedies, and talk shows, the soap opera was traditionally a fixture in the American broadcast networks' daytime schedules"2. As for the documentary, Figure 1 below shows the first train crossed the United States in $1869^{3}$. Interestingly, it can be noted that all these shows are taken from and represent one culture (USA), whereas the textbooks are designed to address Arab countries, as mentioned earlier in this study and also as the authors of these textbooks claimed (p. 12). The author will elaborate more on this point in his analysis. Yet, we can easily suggest as an alternative a number of TV shows that are very popular in Saudi context, i.e. Tash ma Tash (comedy show) or Althaminah (talk show). However, the focus of this study is not to localise the textbooks as some earlier studies suggested in the literature of this study (Mahboob and Elyas 2014). Localising the current EFL textbooks is only part of the solution. The scope of this study is beyond textbook localisations. We need our students to be open to a number of cultures representing English language around the world, including indeed to students' own cultures. Apparently, this is why many researchers (e.g. Alptekin 1993; Cortazzi and Jin 1999; Shin et al. 2011; Mckay 2002; Troudi 2005) suggest the significance of including international cultures in EFL textbook materials. Likewise, Seidhofer (2003) believed that due to the rapid spread of English, countries from expanding circles should be included in mainstream subjects of EFL materials. It is believed that such varieties of culture within EFL textbooks will help our learners to be more engaged in L2 learning and allow them to participate and share knowledge and personal experience without jeopardizing their own culture. According to Cunningsworth (1984; 1985) and Bao (2006), "A thoughtful incorporation of culture in textbooks may help learners to communicate effectively in cross-cultural situations and assist them in becoming tolerant and receptive to values of other cultures" (Bao 2006: 112).

\section{The Dominance of Western Culture Represented on Some Local Events and Neighbourhoods}

Similarly, in Unit 6, Lesson A, students are supposed to talk about their neighbourhoods and some local events where they live. Nonetheless, it can be noticed 
Table 1. Topics Analyzed in Touchstone Books 1 and 2

\begin{tabular}{|c|c|c|}
\hline Topics analysed & Examples given for each topic & Type of culture represented in each topic \\
\hline \multirow{2}{*}{ TV programmes } & \multirow{2}{*}{$\begin{array}{l}\text { Soap opera, talk show, game show, } \\
\text { sitcom, and documentary }\end{array}$} & Western (USA) \\
\hline & & Inner circle \\
\hline \multirow{2}{*}{$\begin{array}{l}\text { Local events and } \\
\text { neighbourhoods }\end{array}$} & \multirow{2}{*}{$\begin{array}{l}\text { Yankee Stadium, The J. Paul Gallery Museum, } \\
\text { Stanley Park, and Parkview Area }\end{array}$} & Western (USA, Canada) \\
\hline & & Inner circle \\
\hline \multirow{2}{*}{ Sports activities } & \multirow{2}{*}{ American football, baseball } & Western (USA, UK) \\
\hline & & Inner circle \\
\hline \multirow{2}{*}{ Clothing style } & \multirow{2}{*}{ Dress pants, sweater, jeans, blouse, and skirt } & Western (USA,UK) \\
\hline & & Inner circle \\
\hline \multirow{2}{*}{ Sightseeing } & \multirow{2}{*}{$\begin{array}{l}\text { New York City, Los Angeles, Minnesota, } \\
\text { and Vancouver }\end{array}$} & Western (USA, Canada) \\
\hline & & Inner circle \\
\hline \multirow{2}{*}{ Currencies } & \multirow{2}{*}{ Dollars \$ } & Western (USA) \\
\hline & & Inner circle \\
\hline \multirow{2}{*}{ Heroes past and present } & \multirow{2}{*}{ Paul Revere } & Western (USA) \\
\hline & & Inner circle \\
\hline
\end{tabular}

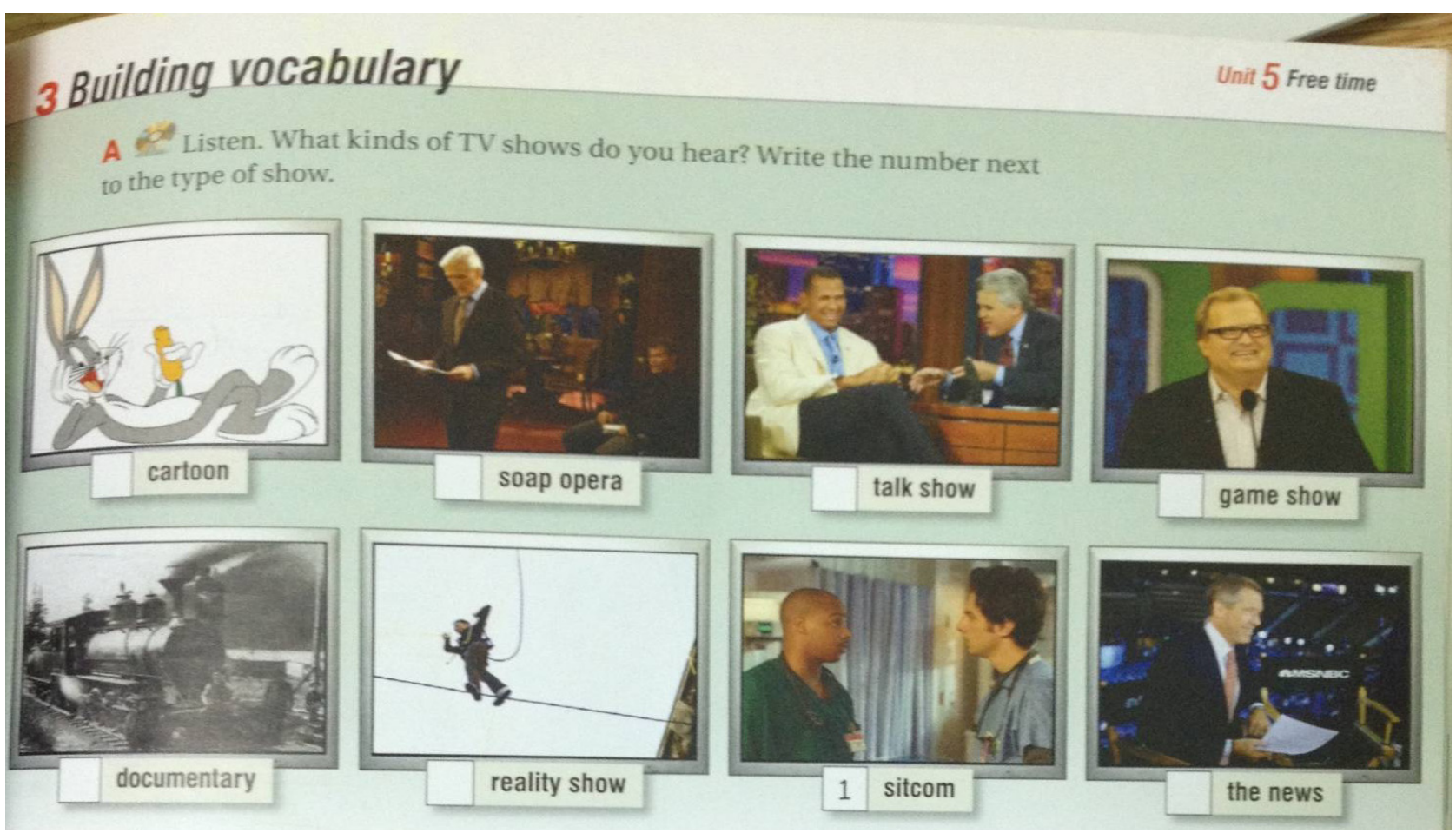

Figure 1. The Dominance of Western Culture Represented on TV Programmes.

that images and pictures given as examples are yet again from the USA. This is evident from the Western names of the shops and restaurants and the picture of the U.S. flag (see Figure 3). The local places exemplified in these materials such as a shopping mall, museum, and stadium are all taken from different cities within inner-circle countries (i.e. Vancouver, Los Angeles, and New York), see Figure 2. 


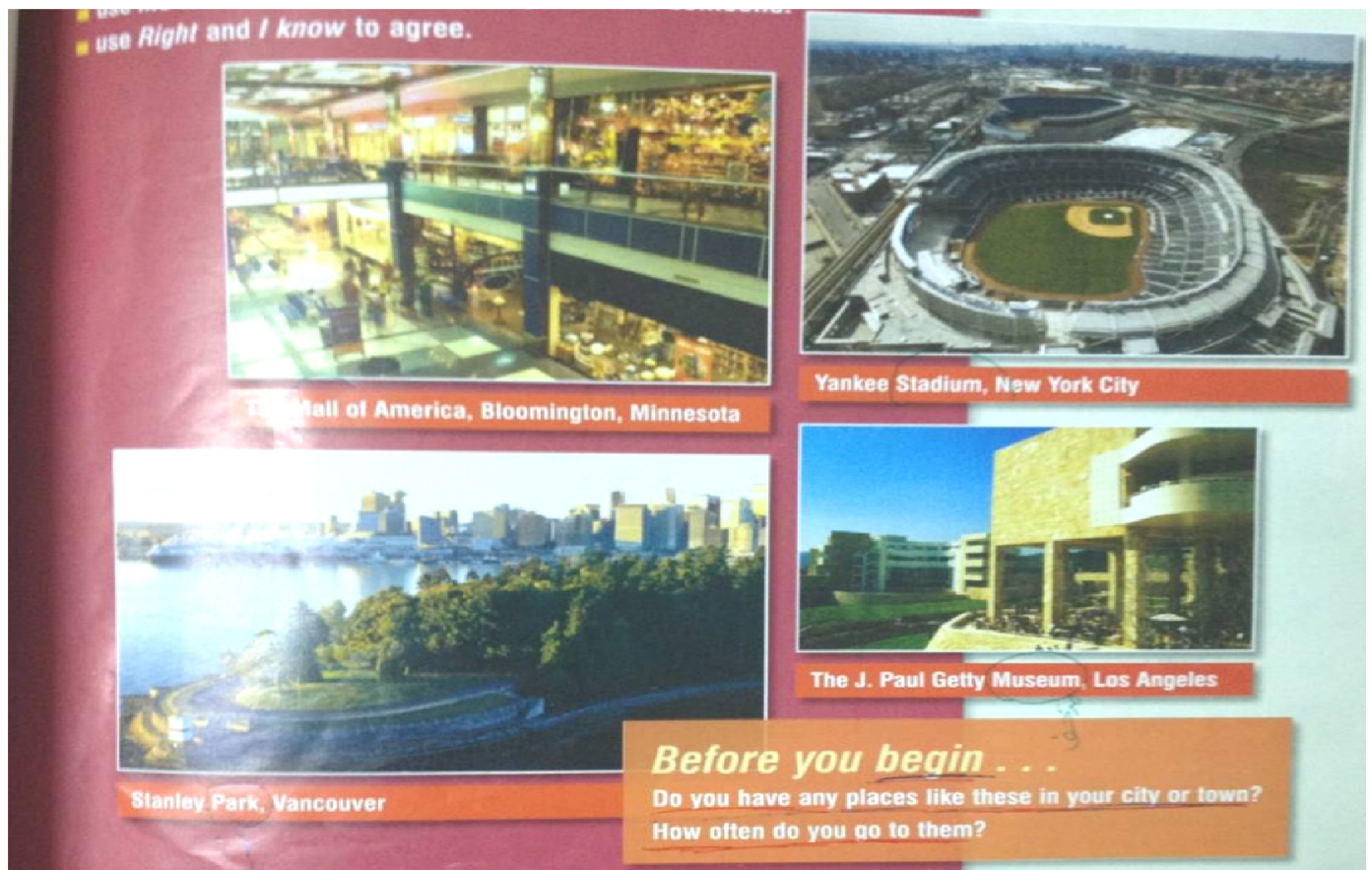

Figure 2. The Dominance of Western Culture Represented on Local Events and Neighbourhoods.
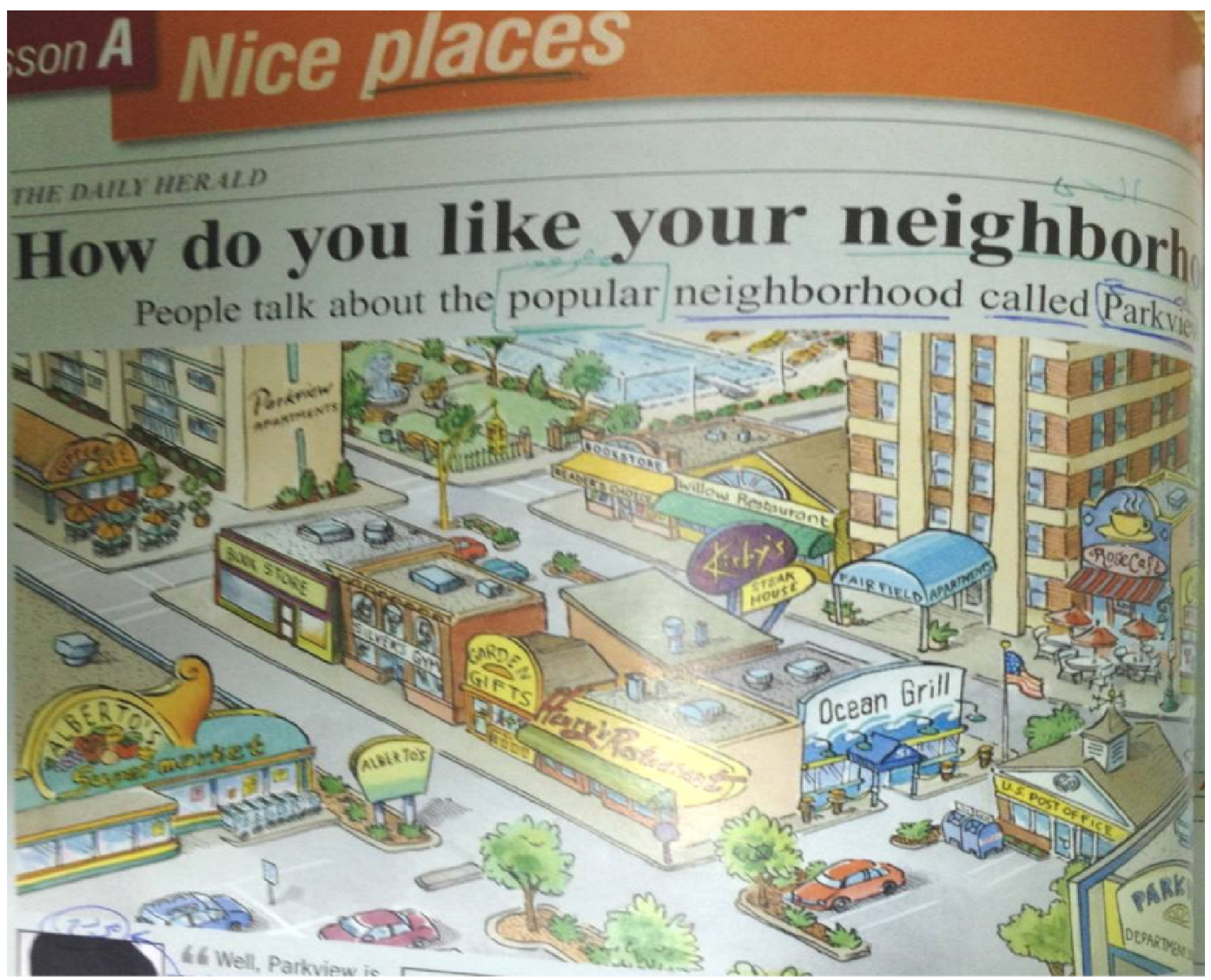

Figure 3. The Dominance of Western Culture Represented on Local Events and Neighbourhoods. 
The author is aware that these events and pictures are just examples, but the question needs to be raised here as to why these events and pictures are only from these countries. They could be taken from other countries that represent the English language (i.e. outer-circle countries) or at least from different cities in the KSA as the lesson is focused on (local events). It has been said in this study as well as several other studies that English is no longer just the language of "native speakers". Millions of people around the world are using English now for multiple purposes. As such, Siddiqie (2011) suggested that "Any effort to impose particular cultural aspects only from a particular country where English is spoken as mother tongue would be a kind of imposing to other cultural group, and might be considered as 'language hegemony or linguistic chauvinism”" (Siddiqie 2011: 111).

This hegemony of English is an important issue that we should be aware of as EFL educators and classroom practitioners. This is why this study attempts to problematize such hegemony within textbooks currently employed in the context addressed. Within the analysis of the study, the author will elaborate more about the potential reasons behind this hegemony of English in general and on EFL textbook materials in particular.

\section{The Dominance of Western Culture Represented on Sport Activities and Games}

In addition to the above, this time American culture is portrayed once again in a topic about sports within these textbooks. Unit 7, Lesson B includes several kinds of sports and exercises people often like to play and/or watch on TV. Figure 4 shows a very popular game in the USA internationally known as American football. The issue may confuse students here because when football is mentioned in a context such as the KSA, everyone understands the most popular game in the world, not the popular game in the USA (American football).

\section{The Dominance of Western Culture} Represented on Clothing Style and Dresses

Moreover, in Unit 8, Lesson A, the topic addressed is about clothing and the kinds of clothes people like to wear. Looking at Figure 5, it can be seen that all the clothes represented in this lesson are from Western cultures and explicitly from the USA. This can also be witnessed by the use of American English words such as "pants" and "sweater". This raises the same question here again as to what about other kinds of clothing from outer-circle or expanding-circle countries. Interestingly, the finding revealed here is also inconsistent with some of the previous studies discussed in the literature (Shin et al. 2011) which suggest that countries in the expanding circle of English speakers (e.g. Korea, Japan, and China) should be included in any mainstream circle (e.g. New Zealand and Canada).

\section{The Dominance of Western Culture Represented on Sightseeing Places}

The same book, in Unit 9, Lesson A, discusses sightseeing and places to visit in the world. Surprisingly, no differences are found in terms of the examples provided. The city portrayed in Figure 6 is from the USA, New York City. The weather shown in this figure also describes typical weather in the Western countries, whether in the USA and/or the UK.

When it comes to sightseeing places around the world, the list may be endless. Examples include but are not limited to the Khalifah Tower in Dubai UAE, the Petronas Twin Tower in Malaysia, the Taj Mahal in India, and the Eiffel Tower in Paris, France. As can be seen from the figure, examples provided in these textbooks are from inner-circle countries.

\section{The Dominance of Western Culture Represented on Currency}

The hegemony of Western culture is also apparent 


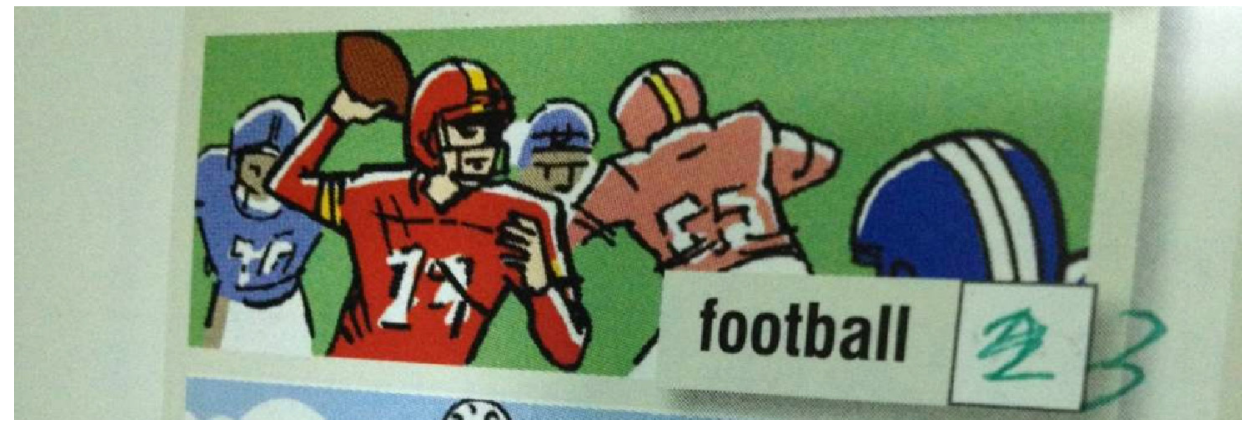

Figure 4. The Dominance of Western Culture Represented on Sport Activities and Games.

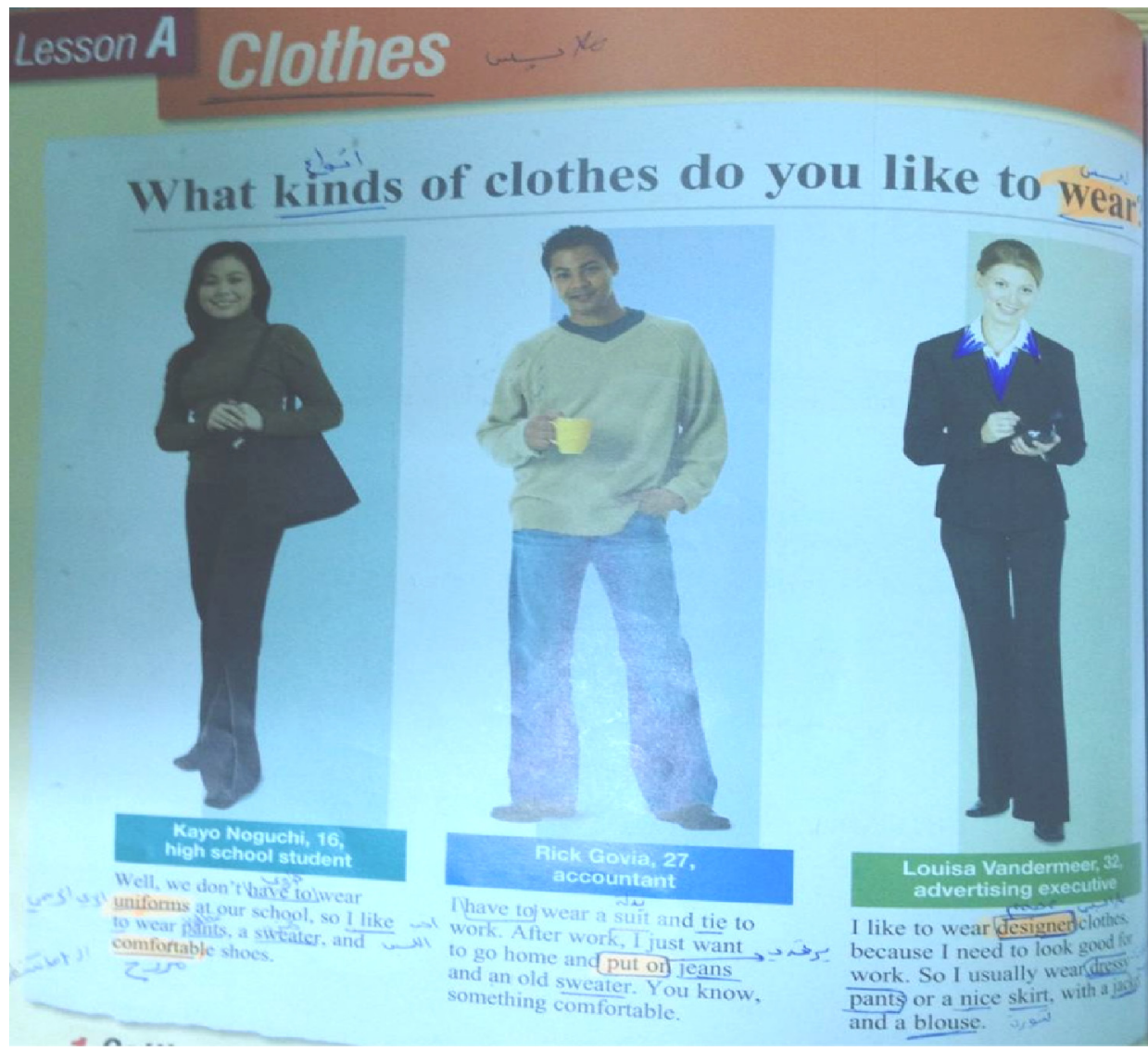

Figure 5. The Dominance of Western Culture Represented on Clothing Style and Dresses.

within the textbook materials in Lesson B from the same unit (8). Here, students learn how to ask questions using how much and how many in addition to using demonstrative pronouns such as "this", "that", "these", and "those". As seen in Figure 7, all product prices given as examples are in American currency (dollar \$), while currencies from other countries tend to be missing. This is depicted repeatedly in other lessons and topics using currency in these textbooks. The local currency, Saudi riyal, is absent. Although the focus of this study is not that textbooks should be somehow localised, throughout the analysis of these materials, the author has realized that students' Eastern culture is nearly missing. 


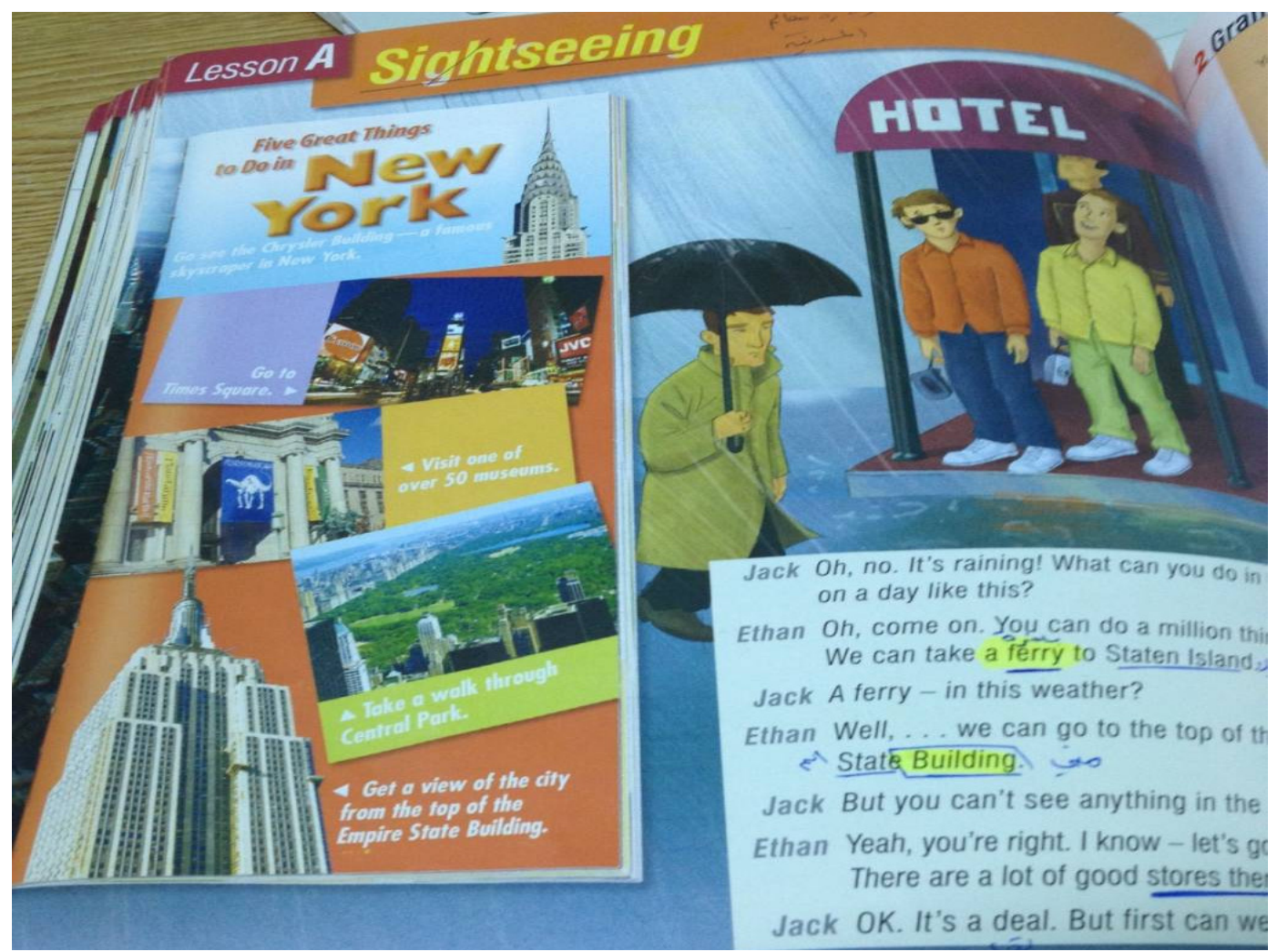

Figure 6. The Dominance of Western Culture Represented on Sightseeing Places.

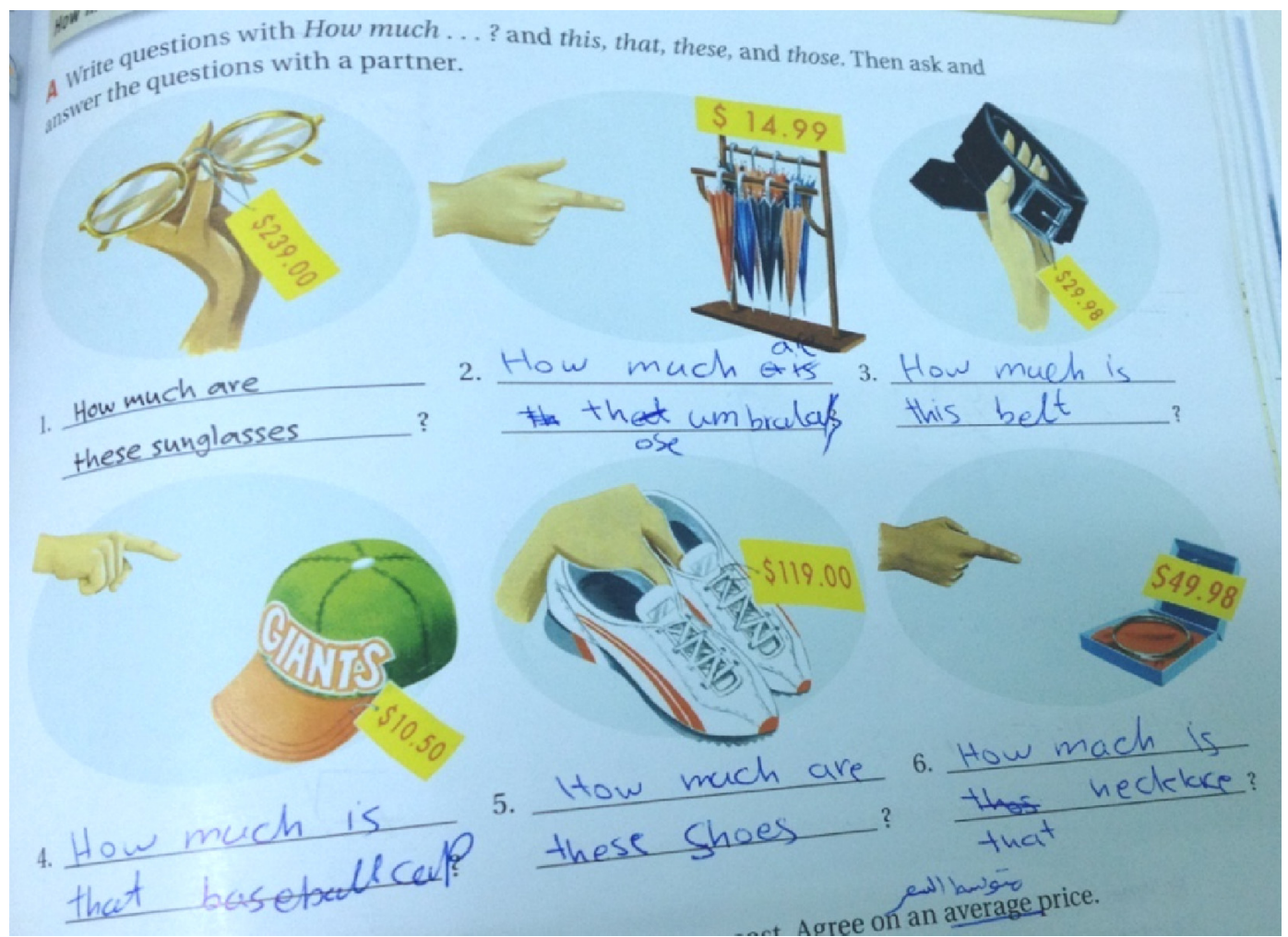

Figure 7. The Dominance of Western Culture Represented on Currency. 
It can be suggested here that this issue should be reconsidered. It is important to have a balance between the cultures portrayed in these materials. On one hand, Western culture should be present in these textbooks, because it is considered the target language in such an EFL context. Importantly, when we say Western culture, it includes countries from both inner and outer circles. On the other hand, Eastern culture representing the students' own culture should also be available. The author is aware that there has been an ongoing debate on this issue within the realm of literature. Some researchers might argue that students can see their own culture represented in other subjects, therefore, it is not necessary to have their culture presented in English textbooks as well. The author's answer to this is that in his context, 99\% of English teachers are native speakers of English (i.e. American, British), and those teachers are interested in knowing something about their students' culture. Therefore, it is suggested that both room and equal opportunities exist for both students and teachers inside classrooms to participate in and talk about their own cultures, whether Eastern or Western.

Very importantly, this is not to say that Western culture is taboo and should be entirely removed or diminished from the content of these EFL textbooks. Students are interested in studying cultures from across the globe, and EFL teachers should take them from what they know to what they do not know; link them from something they are familiar with to what they are not familiar with-with an emphasis on respecting all cultures and nations in the world accordingly.

Throughout the analysis of these textbook materials, it can be deduced that the same problem is perpetuated in all examples listed above. Western culture, particularly from inner-circle countries (USA, UK, and Canada) is the most dominant in these textbooks. It is also important to note that the students' culture, which is Eastern culture in this context, is to a large extent missing. Considering the studies reviewed in the literature, this hegemony might be interpreted as a result of political pressures practised by the US government following the events of 9/11 (Mahboob and Elyas 2014). Such continual pressure was evidenced later by the introduction of the English language at primary schools across the KSA "in order to expose its youth to the idea of acceptance and tolerance of others" (the USA and the West) (Mahboob and Elyas 2014: 130).

It has been stated throughout this study that this domination of EFL materials by English and Western culture was not only observed within the KSA. It was also witnessed by other researchers as an "imperialistic tool" (Phillipson 1992) and a "missionary language" (Pennycook 2003; Wong and Canagarajah 2009). Similarly, Troudi (2005) suggested that due to the political and cultural dominance of the United States, many countries have opted for the American variety of English, and this is reflected in many ELT materials that solely represent American culture.

Accordingly, it is rather significant to mention that the finding of this study is not aimed to oppose Western culture overall nor to accept the hegemony currently portrayed in many EFL textbooks in the KSA. It is, however, to support the inclusion of a variety of cultures within EFL materials. This variety should include the local culture, which represents the students' culture in any EFL context, in addition to the Western culture that represents the target language. It should also incorporate a variety of "Englishes" from around the world (i.e. inner-circle, outer-circle, and expanding-circle countries).

In order to address the second research question, this study also argues that the mainstream topics within these materials are limited in terms of student's needs and interests. It is suggested that common topics such as sports, holidays, and hobbies are quite popular and as such people often like to discuss these issues. 
Nonetheless, it is also important to consider that not all students favour talking about these traditional issues, especially at a university level. From personal experience as an EFL teacher for almost seven years now, the author can safely claim that the majority of topics represented in the content of these materials only address enjoyable activities according to the society in question. However, some students are financially responsible for their families and do not have time to watch a football match as they study in the morning and work in the evening; such students may not be able to travel on a summer holiday or go out with friends during the weekend (the current topics addressed in these textbooks).

Therefore, in light of the study, it is suggested that these topics do not appear to be relevant to students at a university level. They are not inspiring to the students, they do not consider each individual student's culture, interest, age, and intellectual level. Most of the topics represented are not intellectually stimulating for students, are not challenging, and/or are unsuitable for a university student level. These topics and themes do not represent anything other than USA culture. In addition, even within this focused culture, the topics represented in these textbooks are limited. There are many societal issues in the USA to discuss and represent a part of the topics discussed (i.e. baseball, American football, and clothing). Most of the topics available in these materials address childish issues. It might be true that the proficiency level for those learners is somehow limited but that does not mean they cannot discuss topics, especially if the topics are appropriate and addressing their current needs and interests. It is commonly believed and understood among classroom practitioners that students become more involved and active if the topics being discussed are interesting and stimulating for them.

Since this part of the study addresses the appropriateness of textbook materials, it is important to mention the criteria according to which these textbooks were selected in this particular context. According to the curriculum committee, which is currently in charge of selecting these textbooks, these textbooks were chosen to meet the main objectives of the ELC in general and students' needs in particular. These objectives were established in light of the following points:

(1) To develop the English language skills of prep-year students;

(2) To develop the academic and study skills of prep-year students;

(3) To prepare prep-year students for the subsequent English language course in the colleges they join after successful completion of the prep-year.

However, looking at these objectives and criteria, it can be seen that these objectives are quite general and focus only on the language skills that students need to complete their prep-year successfully. It seems that most English language textbooks available in the market are primarily designed to develop language skills for international students around the world. Thus, it does not seem to the author that there is a clear-cut system for choosing appropriate textbooks in this particular context. The objectives mentioned above do not specifically refer to anything related to a student's culture, age, needs, and interests; they only focus on developing language skills for students. This indicates that the criteria of choosing the textbooks are almost absent in this institution. Needless to say, it is vital for any academic institution to have its own internal aims and criteria of which appropriate textbooks are selected and then employed. In other words, it is the university's responsibility as well as the people who are involved to choose an appropriate textbook for their learners as opposed to publishers or the authors themselves. The criteria for choosing textbook materials at any academic institution should be clearly established to fit its own setting, taking into consideration students' needs, cultures, ages, interests, and intellectual levels. The topics discussed and represented in these materials should also be 
stimulating and challenging for students. Those who are in charge of selecting these textbooks may not be aware of these important issues as they may not be trained properly to select the relevant textbooks. They may lack knowledge about these curriculum issues. It is recommended thus in the future that universities should arrange training sessions to train those people regarding how to select the textbook materials. They should be trained to examine these textbooks carefully before selecting them, and they should look at topics represented in these books and see if they are relevant to the students or not.

More to the point, this issue related to the inappropriateness of EFL textbooks to students' needs is also mirrored in Saudi context. Mahib ur Rahman and Alhaisoni (2013: 115) suggested that "Similar to many other countries the syllabus designers and higher authorities of various schools and universities of Saudi Arabia are also unable to choose an appropriate textbook to meet the learners' needs". Alternatively, it is important to involve students in issues more related to their current needs. Considering this particular context, examples include and are not limited to societal problems such as the absence of father and/or mother figures in Saudi families, the high divorce rate, joblessness, and the high rate of car accidents. According to a study conducted by Hassan and Abdel-Aty (2013), assistant professor of transportation engineering at King Saud University, "There were 600,000 car crashes recorded in the Kingdom in 2012, resulting in the death of around 7,638 people" ${ }^{\text {"4 }}$. Other issues such as health topics-obesity, diabetes, and drug addiction-can also be considered in these textbooks. We should encourage students to avoid bad habits such as eating large amounts of fast food, drinking soft drinks, and smoking. It is crucial to raise student awareness regarding these health issues.

Conversely, we should encourage students to go to the gym or partake in some accessible exercises (i.e. walking, jogging). These societal concerns related either to the students or to the area they live in should be present within these materials. It is vital to take advantage of these textbooks and allow students to be engaged in and also aware of such problems. This is, importantly, not to suggest that common entertaining topics such as travelling and hobbies should be diminished. Both should be available and approached within the content of these textbooks. People often enjoy talking about things they are interested in and concerned about. Y. Freeman and D. Freeman (2003) and Troudi (2005) recommended that "These topics need to be relevant to their daily experiences and concerns. Drawing on students' experiences, activities will have real meaning beyond the learning of linguistic and structural items" (Troudi 2005: 123).

Consequently, in order to redress these concerns in the EFL textbooks, there have been some suggestions, For example, Mahib ur Rahman and Alhaisoni (2013) suggested a Needs Analysis (NA) programme to develop EFL materials in the KSA. We can also add here that EFL teachers, the cornerstone of any language-learning context, need to be consulted and involved in choosing the appropriate materials. Teachers deal with students on almost a daily basis, and therefore they must acknowledge students' needs. Troudi (2005: 124) confirmed this limitation of teachers' roles, "Most teachers are not involved in second language policies and will have no choice but to use the variety chosen by those in charge of TESOL curricula". This is not the focus of this study, but since we are discussing EFL materials, such an issue highlighting the teacher's role must be mentioned.

It is recommended to incorporate a variety of cultures representing the English language within EFL materials. However, it is also widely believed and recognized that the majority of EFL textbooks writers are native English speakers. According to Alptekin (1993: 138), "Most textbooks writers are native speakers who consciously or unconsciously transmit the views, values, beliefs and feelings of their own English society". This paucity of bilingual English 
textbook writers has to be acknowledged. So it is important to encourage bilingual and multilingual English-speaking educators to write English textbooks and materials. We must admit, it is quite difficult for a native English speaker to write a textbook that is free from his/her own culture (Shin et al. 2011).

\section{CONCLUSIONS}

This small-scale critical study aimed at challenging and problematizing the English language textbooks being employed within a certain context in the KSA. The reason behind such a study was to raise awareness about the necessity of representing a variety of cultures that English language represents within these textbooks. It also aimed to show Saudi educators in particular and Arabs in general that Western culture was the dominant culture portrayed in the majority of these English materials. Surprisingly, this study revealed that the Western culture portrayed in these textbooks was mainly from inner-circle countries such as the USA, the UK, and Canada; while other countries from outer- or expanding-circle countries seemed to be marginalised.

This study also argues that the current textbooks used in the KSA are insufficient in terms of learners' needs and concerns. The study then suggested some solutions and recommendations to develop textbook materials within the KSA in the future and perhaps in other similar EFL settings. In light of the findings of this study, EFL teachers, whether they know or not, play a role in perpetuating this problem. This is why the author decided to take a further step to approach this dilemma, which currently is seen as a taken-for-granted phenomenon amongst the majority of (if not all) academic institutions in the KSA. Finally, one essential issue must be mentioned here: CDA within the realm of educational research is neutral or apolitical nor serves hidden agendas. It is rather implemented to redress or reveal issues that might be somehow marginalised in the content of these English-language materials (Troudi 2014). To do so, we departed from the point and belief suggesting that "TESOL teacher education needs to look at the nature of education with the lenses of the critical paradigm as well as post-structuralism, cultural studies and social constructivism" (Canagarajah 1999; Pennycook 1998; 1999; 2000) (cited in Troudi 2005: 119).

\section{Notes}

1. Touchstone's introduction section, p. IV.

2. See http://www.wikipedia.org.

3. Touchstone, class audio level 1.

4. See http://www.moi.gov.sa; (Ministry of Interior) Kingdom of Saudi Arabia.

\section{References}

Akbari, R. 2008. "Transforming Lives: Introducing Critical Pedagogy Into ELT Classrooms." ELT Journal 3(1):276-282.

Alfahadi, A. 2012. "Saudi Teachers' Views on Appropriate Cultural Models for EFL Textbooks: Insights Into TESOL Teachers' Management of Global Cultural Flows and Local Realities in Their Teaching Worlds." Unpublished PhD dissertation, The University of Exeter.

Almurabit, I. 2012. "A Closer Look at an English Language Curriculum of a Community College in Saudi Arabia." English Language Teaching 5(8):226-242.

Alptekin, C. 1993. "Target-Language Culture in EFL Materials.” ELT Journal 47(2):136-143.

Bao, D. 2006. "Developing EFL Materials for Local Markets: Issues and Considerations." Pp. 52-76 in Focus on ELT Materials, edited by J. Mukundan. Selangor Darul Ehsan: Pearson Malaysia.

Berns, M. 2010. Concise Encyclopaedia of Applied Linguistics. NY: Elsevier.

Bett, J. and F. Indoshi. 2009. "The Nature of Interaction in English Language Classrooms.” The International Journal of Learning 16(7):218-227.

Blommart, J. and C. Bulcaen. 2000. "Critical Discourse Analysis.” Annual Review of Anthropology 29:447-466.

Canagarajah, A. S. 1996. "From Critical Research Practice to Critical Research Reporting." TESOL Quarterly 30(2):321-330.

—. 1999. Resisting Linguistic Imperialism in English Teaching. Oxford: Oxford University Press. 
Cortazzi, M. and L. Jin. 1999. "Cultural Mirrors: Materials and Methods in the EFL Classrooms." Pp. 196-219 in Culture in Second Language Teaching and Learning, edited by E. Hinkel. Cambridge: Cambridge University Press.

Crystal, D. 1997. English as a Global Language. Cambridge: Cambridge University Press.

Cunningsworth, A. 1984. Evaluation and Selecting EFL Teaching Materials. London: Heinemann Educational Books.

Cunningsworth, A. and D. Horner. 1985. "The Role of Simulations in the Development of Communication Strategies." System 13(3):211-218.

Dijk, V. 1995. "Aims of Critical Discourse Analysis." Japanese Discourse 1(1):17-27.

- 2008. Critical Discourse Analysis. Retrieved October 1, 2014 (http://www.discourses.org/OldArticles/Critical\% 20discourse\%20analysis.pdf).

Fairclough, N. 1995. Critical Discourse Analysis: The Critical Study of Languages. Edinburgh: Pearson Education Limited.

- 2003. Analysing Discourse: Textual Analysis for Social Research. New York: Routledge.

Fairclough, N. and L. Chouliaraki. 2007. Discourse in Late Modernity: Rethinking Critical Discourse Analysis. Edinburgh: Edinburgh University Press.

Freeman, Y. and D. Freeman. 2003. "Struggling English Language Learners: Keys for Academic Success." TESOL Journal 12(3):5-10.

Freire, P. 1970. Pedagogy of the Oppressed. New York: Seabury Press.

Giroux, H. A. 1988. Teachers as Intellectuals: Toward a Critical Pedagogy of Learning. Boston: Bergin \& Garvey.

Gray, J. 2002. "The Global Coursebook in English Language Teaching." Pp. 151-167 in Globalization and Language Teaching, edited by D. Block and D. Cameron. London: Routledge.

Gulliver, T. 2010. "Immigrant Success Stories in ESL Textbooks." TESOL Quarterly 44:725-745.

Hall, J. K. 2002. Teaching and Researching Language and Culture. London: Longman.

Hall, J. K. and W. Eggington, eds. 2000. The Sociopolitics of English Language Teaching. Tonawanda, NY: Multilingual Matters.

Hassan, H. M. and M. A. Abdel-Aty. 2013. "Exploring the Safety Implications of Young Drivers' Behavior, Attitudes and Perceptions." Accident Analysis \& Prevention 50:361-370.

Jenkins, J. 2006. "The Spread of English as an International Language: A Testing Time for Testers." ELT Journal 60(1):42-50.

Kayaoglu, M. 2011. "A Critical Appraisal of the Language Textbook." Journal of Kirsehir Education Faculty
12(4):341-356.

Kincheloe, J. L. and P. McLaren. 2002. "Rethinking Critical Theory and Qualitative Research." Pp. 87-138 in Ethnography and Schools: Qualitative Approaches to the Study of Education, edited by Y. Zou and E. T. Trueba. Lanham, MD: Rowman \& Littlefield.

Kumaravadivelu, B. 2001. Beyond Methods: Macrostrategies for Language Teaching. New Haven and London: Yale University Press.

_. 2006a. "Critical Classroom Discourse Analysis." TESOL Quarterly 33(3):453-484.

- 2006b. "Dangerous Liaison: Globalization, Empire and TESOL." Pp. 1-26 in (Re-) Locating TESOL in an Age of Empire, edited by J. Edge. UK: Palgrave Macmillan.

Liu, Y.-B. 2005. "Discourse, Cultural Knowledge and Ideology: A Critical Analysis of Chinese Language Textbooks." Pedagogy, Culture and Society 13(2):233-264.

Macedo, D., P. Gounari, and B. Dendrinos. 2004. The Hegemony of English. Boulder: Paradigm.

Mahboob, A. and T. Elyas. 2014. "English in the Kingdom of Saudi Arabia." World Englishes 33(1):128-142.

Mahib ur Rahman, M. and E. Alhaisoni. 2013. "Teaching English in Saudi Arabia: Prospects and Challenges." Academic Research International 4(1):112-118.

McKay, S. L. 2002. Teaching English as an International Language: Rethinking Goals and Perspectives. New York: Oxford University Press.

Murayama, Y. 2000. "The Promotion of Intercultural Understanding in English Language Teaching: An Analysis of Textbooks and Teacher Training Courses for Upper Secondary Schools in Japan." Unpublished master thesis, The University of York, UK.

Nikou, F. R. and F. Soleimani. 2012. "The Manifestation of Culture in Iranian and Turkish High School English Text Books." Academic Research International 2(3):646-656.

Pennycook, A. 1998. English and the Discourse of Colonialism. London: Routledge.

—. 1999. "Introduction: Critical Approaches to TESOL." TESOL Quarterly 33(3):329-348.

— 2000. "The Social Politics and the Cultural Politics of Language Classrooms." Pp. 89-103 in The Sociopolitics of English Language Teaching, edited by J. K. Hall and W. Eggington. Tonawanda, NY: Multilingual Matters.

- 2001. Critical Applied Linguistics: A Critical Introduction. London: LEA.

_ . 2003. "Global Englishes, Rip Slyme, and Performativity." Journal of Sociolinguistics 7(4): 513-533.

Phillipson, R. 1992. Linguistic Imperialism. Oxford: Oxford University Press.

. 2008. "English in Globalisation, a Lingua Franca or a Lingua Frankensteinia?” World Englishes 27(2):250-267. 
Quang, V. D. 2007. "Critical Applied Linguistics: Concerns and Domains." Tap Chi Khoa Hoc 23(1):34-50.

Ramirez, A. G. and J. K. Hall. 1990. "Language and Culture in Secondary Level Spanish Textbooks." The Modern Language Journal 74(1):48-65.

Rubin, H. J. 2012. Qualitative Interviewing: The Art of Hearing Data. 3rd ed. USA: SAGE.

Saxena, M. and T. Omoniyi. 2010. Contending With Globalization in World Englishes. UK: Short Run Press Ltd.

Seidlhofer, B. 2003. A Concept of International English and Related Issues: From "Real English" to "Realistic English”. Strasbourg: Council of Europe. Retrieved (http:// www.coe.int/t/dg4/linguistic/source/seidlhoferen.pdf).

Shin, J., Z. R. Eslami, and W.-C. Chen. 2011. "Presentation of Local and International Culture in Current International English-Language Teaching Textbooks." Language, Culture and Curriculum 24(3):253-268.

Siddiqie, S. 2011. "Intercultural Exposure Through English Language Teaching: An Analysis of an English Language Textbook in Bangladesh." Pan-Pacific Association of Applied Linguistics 15(2):109-127.

Smith, S. C. 1998. British Imperialism: 1750-1970. Cambridge: University Press.

Tollefson, J. 2002. Language Policies in Education: Critical Issues. Mahwah, New Jersey: Lawrence Erlbaum.

Tomlinson, J. 1999. Globalisation and Culture. Cambridge: Polity Press.
Troudi, S. 2005. "Critical Content and Cultural Knowledge for Teachers of English to Speakers of Other Languages." Teacher Development 9(1):115-129.

. 2014. "Becoming a Critical Researcher in Language Education and TESOL." Manuscript accepted for publication in CUP edited volume.

Weber, R. P. 1990. Basic Content Analysis. Newbury Park, CA: Sage.

Weninger, C. and T. Kiss. 2013. "Culture in English as a Foreign Language (EFL) Textbooks: A Semiotic Approach." TESOL Quarterly 47(4):1-23.

Wodak, R. and M. Meyer. 2001. Methods of Critical Discourse Analysis. London: SAGE.

- 2009. Methods of Critical Discourse Analysis. London: SAGE.

Wong, M. S. and S. Canagarajah, eds. 2009. Christian and Critical English Language Educators in Dialogue: Pedagogical and Ethical Dilemmas. New York, NY: Routledge.

\section{Bio}

Omar Alsaif, EFL teacher at Taibah University, Madinah KSA, Ph.D. candidate in TESOL, Faculty of Education, University of Exeter, UK; research fields: language teaching, textbooks materials, classroom discourse, interculture communication. 